\section{RNA Extraction Method from Fruit Tissue High in Water and Sugar}

\author{
Angela R. Davis ${ }^{1}$ \\ U.S. Department of Agriculture, Agricultural Research Service, South \\ Central Agricultural Research Laboratory, P.O. Box 159, Hwy. 3 West, \\ Lane, OK 74555
}

\section{Amnon Levi}

U.S. Department of Agriculture, Agricultural Research Service, U. S. Vegetable Laboratory, 2700 Savanna Highway, Charleston, SC 29414

\author{
Sungil Kim and Stephen R. King \\ Vegetable and Fruit Improvement Center, Department of Horticultural \\ Sciences, Texas A\&M University, College Station, TX 77843
}

\section{Alvaro Hernandez \\ University of Illinois at Urbana, Champaign Biotechnology Center, W. M. Keck Center for Comparative and Functional Genomics, 1201 W. Gregory Dr., Room 356, Urbana, IL 61801}

Additional index words. RNA isolation, rapid, cucurbit, tomato, liquid removal, sugar removal

\begin{abstract}
RNA isolation from ripe fruit can be complicated by high concentrations of sugar and water. These sugars interfere with RNA extraction often resulting in low RNA quality and quantities, and high water concentrations dilute the RNA, making isolation difficult. We report a simple but novel method by which the majority of the excess sugar and water in mature fruit of tomato (Lycopersicon esculentum Mill.), watermelon [Citrullus lanatus (Thunb.) Matsum. \& Nakai], and muskmelon (Cucumis melo L.) can be easily removed from tissue before RNA extraction. This method produced quality RNA in a shorter time than the currently accepted method for fruit tissue RNA isolation and does not require liquid nitrogen or a freeze dryer.
\end{abstract}

RNA is used in a multitude of laboratory experiments from Northern blots to reverse transcriptase-polymerase chain reactions (RT-PCR). Isolating high-quality RNA is important in the process of gene discovery and for studying temporal expression of genes during sequential developmental stages of plants. Unfortunately, the instability of RNA and the ubiquitous nature of RNases make RNA highly susceptible to degradation

Received for publication 24 Mar. 2006. Accepted for publication 10 May 2006. We thank Anthony Dillard, Amy Helms, and Haejeen Bang for providing valuable technical support. Mention of trade names or commercial products in this article is solely for the purpose of providing specific information and does not imply recommendation or endorsement by the U.S. Department of Agriculture. All programs and services of the U.S. Department of Agriculture are offered on a nondiscriminatory basis without regard to race, color, national origin, religion, sex, age, marital status, or handicap. The article cited was prepared by a USDA employee as part of his or her official duties. Copyright protection under U.S. copyright law is not available for such works. Accordingly, there is no copyright to transfer. The fact that the private publication in which the article appears is itself copyrighted does not affect the material of the U.S. Government, which can be freely reproduced by the public.

${ }^{1}$ To whom reprint requests should be addressed; e-mail adavis-usda@lane-ag.org.
(Ausubel et al., 1997). Further complications arise from contaminants in the original tissue that render the isolated RNA unfit for downstream applications. For example, tissues from ripe fruit and seeds often have high concentrations of lipids, phenolic compounds, and polysaccharides and low concentrations of RNA molecules, causing low recovery or difficulty quantifying the sample (Asif et al., 2000; Callahan et al., 1989; Levi et al., 1992; Loomis, 1974; Taylor and Powell, 1982). Several groups have reported alternative protocols improving RNA yields and reducing contamination problems inherent in some fruit tissue (Asif et al., 2000; Callahan et al., 1989; Gehrig et al., 2000; Levi et al., 1992; Logemann et al., 1987; Mozer, 1980; Taylor and Powell, 1982). Callahan et al. (1989) reported a method to remove excess water from peach flesh to isolate high-quality RNA. However, this method requires the use of a freeze dryer to remove the excess moisture, which in turn concentrates the carbohydrates present in the dried sample. It may take up to $7 \mathrm{~d}$ to completely dry large or multiple samples, which increases the exposure time of RNA to oxidation and RNases, increases the potential for sample thawing resulting from mechanical failure, and slows down the isolation process. Additionally, the freeze-drying process makes the tissue difficult to grind by mortar and pestle or Polytron (Brinkmann
Instruments Inc., Westbury, N.Y.). Therefore, these samples often do not fully homogenize in commercial RNA extraction solutions.

In this study, we report an efficient and economical procedure to reduce water and carbohydrate content in fruit tissue. The resultant RNA is of sufficient quality for downstream applications such as RT-PCR and $5^{\prime}$ and $3^{\prime}$ RACE.

\section{Materials and Methods}

Fruit and sample preparation. Ripe fruit from watermelon ('Tri-x 313', 'Illini Red', and 'Summer Gold'), ripe red tomatoes (Roma type, 'Rutgers', and 'T5020'), and ripe and immature muskmelon ('Magnum 45'35 d, and $2 \mathrm{~d}$ postpollination) were used for this study. They were grown and collected at the South Central Agricultural Research Laboratory in Lane, Okla. The fruit were rinsed with deionized water in the field, and small samples of flesh tissue $(\approx 5-10 \mathrm{~g})$ were excised and processed using our juice extraction RNA isolation method and a conventional RNA freeze-dried method described subsequently. All glassware and utensils were purchased sterile or were cleaned with $\mathrm{RNa}$ seZap (Ambion Inc., Austin, Tex.), and rinsed with RNase-free water before each use. Utensils used in the field were washed between samples with $95 \%$ ethanol and allowed to air dry. Total soluble solids (Brix) were determined using a Reichert 10,430 refractometer (Cambridge Instruments Inc., Buffalo, N.Y.) on juice squeezed from fruit flesh tissue using a 7-inch sap extractor.

Juice extraction RNA isolation method. Flesh tissue was excised from ripe fruit; the juice was removed and discarded by squeezing the excised flesh with a sap extractor (such as 7-inch Sap Extractor; Peaceful Valley Farms, Grass Valley, Calif.). The pulp was immediately scraped into a preweighed, prelabeled (etched, so liquid nitrogen would not remove the label) sterile 50-ml conical polypropylene tubes (Blue Max; Becton Dickinson Labware, Franklin Lakes, N.J.) that contained a predetermined amount of TRIzol (GibcoBRL Invitrogen; Life Technologies, Gaithersburg, Md.) reagent. For our purposes, $5 \mathrm{ml}$ was used. The sample was then immediately placed on wet ice for transport to the laboratory. Liquid nitrogen should be used if available as an extra precaution against degradation. The tubes were reweighed and more TRIzol was added to bring the concentration to $1 \mathrm{ml}$ of TRIzol per $100 \mathrm{mg}$ of sample. Samples were homogenized at room temperature with a Brinkmann Polytron PT $10 / 35$ with a $20-\mathrm{mm}$ grinding blade for 60 to $90 \mathrm{~s}$. The samples were not allowed to heat or froth. Polytron operation was performed in a fume hood with protective clothing. The homogenized samples were stored at $-80^{\circ} \mathrm{C}$ until the RNA extraction procedure was performed. Total RNA was extracted using the TRIzol reagent following the company's protocol. Both 
Table 1. Yield and 260/280 ratio of RNA samples isolated using our juice extraction method and the conventional freeze-dried method.

\begin{tabular}{|c|c|c|c|c|c|c|c|c|c|c|}
\hline & \multicolumn{5}{|c|}{ Freeze-dried method } & \multicolumn{5}{|c|}{ Juice extraction method } \\
\hline & $\begin{array}{c}\text { Number of } \\
\text { samples }\end{array}$ & $\begin{array}{l}\text { Yield average } \\
\quad\left(\mathrm{ug} \cdot \mathrm{g}^{-1}\right)^{\mathrm{z}}\end{array}$ & $\begin{array}{l}\text { Standard } \\
\text { deviation }\end{array}$ & $260 / 280$ & $\begin{array}{l}\text { Standard } \\
\text { deviation }\end{array}$ & $\begin{array}{c}\text { Number of } \\
\text { samples }\end{array}$ & $\begin{array}{l}\text { Yield average } \\
\left(\mathrm{ug} \cdot \mathrm{g}^{-1}\right)^{\mathrm{z}}\end{array}$ & $\begin{array}{l}\text { Standard } \\
\text { deviation }\end{array}$ & $260 / 280$ & $\begin{array}{l}\text { Standard } \\
\text { deviation }\end{array}$ \\
\hline Watermelon & 15 & 34 & 13 & 2.1 & 0.3 & 12 & 11 & 6 & 2.2 & 0.5 \\
\hline Tomato & 6 & 42 & 21 & 2.1 & 0.4 & 6 & 13 & 5 & 2.2 & 0.7 \\
\hline Cantaloupe & & & & & & 2 & 15 & 8 & 2.0 & 0.9 \\
\hline
\end{tabular}

${ }^{\mathrm{z}}$ Total RNA yield from $1 \mathrm{~g}$ fresh sample.

optional steps to reduce polysaccharide contamination were performed. This included a centrifugation step and a high salt precipitation step.

Testing RNA quality. Agarose and denaturing gel electrophoresis, Northern blotting, and PCR were performed using standard techniques (Ausubel et al., 1997). 5' and 3' RACE (GibcoBRL Invitrogen; Life Technologies) was performed according to company protocols. The denaturing RNA gel and Northern blot experiments were run using the NorthernMax, BrightStar PsoralenBiotin, and BrightStar BioDetect kits (Ambion) following the company's protocol. Agarose gels were visualized on a Kodak Image Station 440CF (Eastman Kodak Co., Rochester, N.Y.) and were used to verify RNA quality and concentration determined by spectral analysis. All isolated RNA samples were diluted in $1 \mathrm{mM} \mathrm{Na} \mathrm{HPO}_{4}$ in nuclease-free water $(\mathrm{pH} 8.3)$ and readings were taken at 260 $\mathrm{nm}$ and $280 \mathrm{~nm}$ wavelengths using a Perkin Elmer Co. ultraviolet/VIS Spectrophotometer Lambda 3B (Wellesley, Mass,). A quartz $100-\mu l$ cuvette was used and the instrument was zeroed using the above diluent. A subset of samples was continuously scanned from $210 \mathrm{~nm}$ to $310 \mathrm{~nm}$ wavelengths using a NanoDrop ND-1000 Spectrophotometer (Wilmington, Del.).

Conventional RNA freeze-dried method. On excision, fruit tissue was immediately placed in a preweighed, prelabeled sterile 50$\mathrm{ml}$ conical polypropylene tube. The tube was immediately placed in liquid nitrogen for transporting to a LabConco Co. Freeze Dryer 18 (Kansas City, Mo.). The samples were freeze-dried under shelf refrigeration at $-35^{\circ} \mathrm{C}$ until samples were fully dry (Callahan et al., 1989). This took from $24 \mathrm{~h}$ to $7 \mathrm{~d}$ depending on the size, number of samples, and the moisture content of the tissue samples. Once lyophilized, the preweighed tubes containing the samples were again weighed and TRIzol reagent was added to a final concentration of $1 \mathrm{ml}$ TRIzol per $100 \mathrm{mg}$ of sample. Samples were homogenized with a Polytron as described previously and stored at $-80^{\circ} \mathrm{C}$ until RNA extraction was performed as described.

\section{Results and Discussion}

Total RNA from 20 mature fruit samples processed using the juice extraction method yielded RNA in the range of 5 to $22 \mu \mathrm{g}$ per $1 \mathrm{~g}$ fresh tissue. The average for the 12 mature watermelons was $11 \mu \mathrm{g} \cdot \mathrm{g}^{-1}$ fresh tissue and the average for six tomatoes was $13 \mu \mathrm{g} \cdot \mathrm{g}^{-1}$ fresh tissue. The average of two mature muskmelon fruits yielded $15 \mu \mathrm{g} \cdot \mathrm{g}^{-1}$ fresh tissue. This was a decrease over the freezedried method, which gave yields of 15 to $57 \mu \mathrm{g}$ per $1 \mathrm{~g}$ fresh tissue from 21 fruit. The average of 15 freeze-dried mature watermelons was $34 \mu \mathrm{g} \cdot \mathrm{g}^{-1}$ fresh tissue and six tomatoes was $42 \mu \mathrm{g} \cdot \mathrm{g}^{-1}$ fresh tissue (Table 1 ). Cantaloupe was not analyzed using the freeze-dried method, but the juice extraction method on immature fruit samples yielded much higher RNA concentrations than on mature fruit. The juice extraction method yielded $236 \mu \mathrm{g} \cdot \mathrm{g}^{-1}$ fresh tissue from imma-
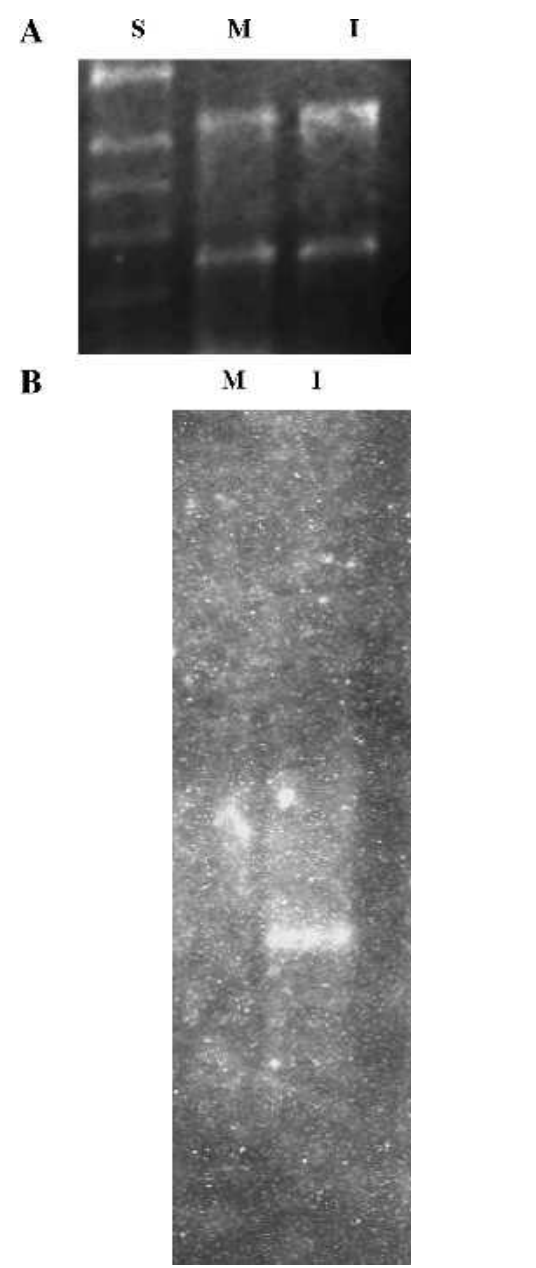

Fig. 1. Denaturing RNA gel (A) and Northern blot (B) of 'Magnum 45' muskmelon mature (M) $35 \mathrm{~d}$ postanthesis and immature (I) $2 \mathrm{~d}$ postanthesis were hybridized with tomato full-length polygalactosidase-inhibiting protein. Lane $\mathrm{S}$ is the Millenium RNA Molecular Weight Markers (Ambion); the band sizes are 1.5, 2, $2.5,3$, and 4 kilobases. ture muskmelon and $146 \mu \mathrm{g} \cdot \mathrm{g}^{-1}$ fresh tissue from immature watermelon. RNA concentrations were verified at the University of Illinois on 17 of the samples using a NanoDrop spectrophotometer. This comparison determined that our analytical spectrophotometer was giving accurate concentration estimates. To determine if our RNA was of sufficient quality to perform accurate concentration estimates using ultraviolet spectrophotometry, we compared our estimated concentrations with samples run on denaturing agarose gels. The spectral data were used to estimate the amount of RNA needed to load each lane of the gels in Figures 1 and 2. These gels demonstrated the RNA was of high quality and can be accurately estimated using a spectrophotometer.

RNA quality was assessed using ultraviolet spectrophotometry (Tables 1 and 2), visualizing intact ribosomal RNA on a denaturing RNA gel (Figs. 1A and 2), detecting message on Northern blots (Fig. 1B), amplifying appropriately sized bands in RT-PCR (data not shown), and sequencing the $5^{\prime}$ and $3^{\prime}$ ends of watermelon genes using RACE (data not shown). Genomic DNA was not detected on denaturing gels (data not shown). Northern blots were performed on muskmelon total RNA purified with the juice extraction RNA isolation method using a tomato pgip probe and produced clean blots (Fig. 1). The results from these methods showed that RNA purified using the juice extraction RNA isolation method was free
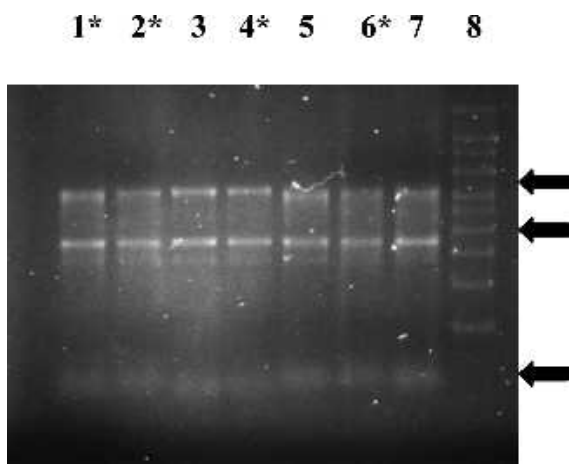

Fig. 2. Denaturing agarose gel showing the relative concentrations of $28 \mathrm{~S}, 18 \mathrm{~S}$, and $5 \mathrm{~S}$ ribosomal RNA. The stared lanes $(1,2,4$, and 6) are watermelon samples prepared using the RNA juice extraction method. Lane 3, 5, and 7 are watermelon samples prepared using the freezedried method. The ribosomal RNAs are marked. Lane 8 is the Millenium RNA Molecular Weight Markers (Ambion); the band sizes are $0.5,1,1.5,2,2.5,3,4,5,6$, and 9 kilobases. 
Table 2. Yield and 260/280 ratio of 17 RNA samples isolated using our juice extraction method and the conventional freeze-dried method and analyzed on a NanoDrop spectrophotometer.

\begin{tabular}{|c|c|c|c|c|c|c|c|c|c|c|}
\hline & \multicolumn{5}{|c|}{ Freeze-dried method } & \multicolumn{5}{|c|}{ Juice extraction method } \\
\hline & $\begin{array}{c}\text { Number of } \\
\text { samples }\end{array}$ & $\begin{array}{l}\text { Yield average } \\
\left(\mathrm{ug} \cdot \mathrm{g}^{-1}\right)^{\mathrm{z}}\end{array}$ & $\begin{array}{l}\text { Standard } \\
\text { deviation }\end{array}$ & $260 / 280$ & $\begin{array}{l}\text { Standard } \\
\text { deviation }\end{array}$ & $\begin{array}{c}\text { Number of } \\
\text { samples }\end{array}$ & $\begin{array}{l}\text { Yield average } \\
\left(\text { ug } \cdot g^{-1}\right)^{z}\end{array}$ & $\begin{array}{r}\text { Standard } \\
\text { deviation }\end{array}$ & $260 / 280$ & $\begin{array}{l}\text { Standard } \\
\text { deviation }\end{array}$ \\
\hline Watermelon & 6 & 25 & 8 & 1.9 & 0.2 & 5 & 13 & 7 & 1.7 & 0.1 \\
\hline
\end{tabular}

${ }^{\mathrm{z}}$ Total RNA yield from $1 \mathrm{~g}$ fresh sample.

from interfering proteins, phenolic compounds, and polysaccharides. Spectrophotometric determination of RNA quality was originally performed on an analytical spectrophotometer. We found our 260/280 ratios were irreproducible, resulting in a high standard deviation. We therefore determined the quality of our RNA using the data from 17 samples analyzed on the NanoDrop spectrophotometer. The data from eight samples isolated using the juice extraction method had an average 260/280 ratio of 1.7 and 9 samples isolated using the freeze-dried method had a ratio of 1.8 (Table 2). These ratios indicate that the two methods are comparable for contaminates.

By eliminating the water and water-soluble material, our method reduces the amount of sample weight and total soluble solids in watermelon by $\approx 90 \%$ (data not shown). However, when we tested the RNA concentration in the eliminated liquid, we found that we lose $\approx 50 \%$ of the RNA to the water-soluble material. This procedure results in a fivefold concentration of the RNA, whereas the freezedried method concentrates the RNA 10-fold. This is likely why the juice extraction method gives lower yields than the freeze-dried method.

Figure 2 shows RNA samples purified using the RNA juice extraction method and the freeze-dried method. This figure shows that the percent of small RNAs present is equivalent in both methods. This demonstrates that the juice extraction method is not prefer- entially isolating large RNA, which suggests that nuclear and cytoplasmic RNA are being retained equally. It is important to note that we may be preferentially selecting for RNA in certain cell types since we may be losing intact cells while squeezing out the liquid.

Removal of water and carbohydrates from juicy fruit is critical for obtaining highquality and sufficient quantities of RNA. The procedure reported in this study can be useful for rapid removal of water and sugar for RNA extraction from a wide array of juicy fruits. It does not require use of a freeze-dryer and reduces the opportunity for RNA degradation resulting from mechanical failure or sample contamination from neighboring samples. It is simple enough to be used in the field, avoiding shipping-related changes in gene expression, and eliminates the need of liquid nitrogen, making it possible to collect RNA samples from almost anywhere. However, liquid nitrogen should be used if available as an added precaution against degradation. Additionally, the juice extraction method overcomes the difficulty homogenizing freeze-dried samples into RNA extraction buffer as a result of accumulated sugars (data not shown).

It is important to understand that certain cells within a given tissue may be more susceptible to removal with the juice or more susceptible membrane disruption and therefore may be prone to RNA losses. We feel this method will be useful for PCR sequenc- ing procedures but may not be a good choice for tissue expression experiments.

\section{Literature Cited}

Asif, M.H., P. Dhawan, and P. Nath. 2000. A simple procedure for the isolation of high quality RNA from ripening banana fruit. Plant Mol. Biol. Rptr. 18:109-115.

Ausubel, F.M., R. Brent, R.E. Kingston, D.D Moore, J.G. Seidman, J.A. Smith, and K. Struhl. 1997. Current Protocols in Molecular Biology. John Wiley and Sons, N.Y.

Callahan, A., P. Morgens, and E. Walton. 1989. Isolation and in vitro translation of RNAs from developing peach fruit. HortScience 24:356-358.

Gehrig, H.H., K. Winter, J. Cushman, A. Borland, and T. Taybi. 2000. An improved RNA isolation method for succulent plant species rich in polyphenols and polysaccharides. Plant Mol. Biol. Rptr. 18:369-376.

Levi, A., G.A. Galau, and H.Y. Wetzstein. 1992. A rapid procedure for the isolation of RNA from high-phenolic-containing tissues of pecan. HortScience 27:1316-1318.

Logemann, J., J. Schell, and L. Willmitzer. 1987. Improved method for the isolation of RNA from plant tissues. Anal. Biochem. 163:16-20.

Loomis, W.D. 1974. Overcoming problems of phenolic and quinones in the isolation of plant enzymes and organelles. Methods Enzymol. 31:528-545.

Mozer, T.J. 1980. Partial purification and characterization of the mRNA from alpha-amylase from barley aleurone layers. Plant Physiol. 65:834-837.

Taylor, B. and A. Powell. 1982. Isolation of plant DNA and RNA. Focus 4:4-6. 